\title{
PERAN STAF ADMINISTRASI DALAM MENANGANI LAPORAN PENJUALAN PADA PT. SINAR PERDANA ADIMULIA JAKARTA BARAT
}

\author{
Edi Junaedi ${ }^{1}$ \\ Dosen Prodi D-III Sekretari Universitas Pamulang \\ edijun6976@gmail.com \\ Lisa Wijaya ${ }^{2}$ \\ Mahasiswa Prodi D-III Sekretari Universitas Pamulang \\ estercha27@gmail.com
}

\begin{abstract}
ABSTRAK-Salah satu parameter keberhasilan suatu perusahaan dinilai dari kemampuan perusahaan dalam memperoleh laba. Perusahaan menuntut agar pihak-pihak yang berkaitan dapat bekerja lebih efisien agar mampu bersaing dan mempertahankan eksistensi perusahaan. Persaingan yang semakin kuat di era globalisasi ini, membuat perusahaan harus bekerja lebih maksimal. Perusahaan membutuhkan suatu laporan dan analisa data dan angka sebagai patokan penilaian sebuah pencapaian perusahaan. Laporan penjualan berfungsi sebagai informasi apakah perusahaan memperoleh keuntungan atau menderita kerugian dan seberapa besar pencapaian target yang dihasilkan. Dalam pembuat laporan penjualan dibutuhkan seorang staf administrasi yang mampu menangani dan mengelola laporan penjualan dengan baik, cepat dan akurat, untuk itu dibutuhkan ketelitian, kecermatan, dan kecepatan, agar laporan terselesaikan tepat waktu, selain itu diperlukan juga kematangan dalam pembuatan laporan, agar data yang dilaporkan benar sesuai fakta di lapangan dan setiap data yang dilaporkan dapat dipercaya dan dapat dipertanggung jawabkan. Rumusan masalah dalam penulisan ini adalah sebagai berikut : 1. Apa saja Peran Staf Administrasi Dalam Menangani Laporan Penjualan Pada PT. Sinar Perdana Adimulia Jakarta Barat? 2. Bagaimana cara menyusun laporan penjualan yang baik, cepat, akurat dan dapat dipertanggung jawabkan sesuai dengan kebutuhan perusahaan?
\end{abstract}

\section{Kata Kunci : Laba, Efisien, Persaingan, Staf Administrasi, Penjualan}

ABSTRACT-One of the parameters of a company's success is judged by the company's ability to make a profit. The company demands that related parties can work more efficiently in order to be able to compete and maintain the company's existence. Competition is getting stronger in this era of globalization, making companies have to work more optimally. The company needs a report and analysis of data and numbers as a benchmark for assessing a company's achievements. Sales report serves as information whether the company made a profit or suffered a loss and how much the achievement of the resulting target. In making a sales report an administrative staff is needed who is able to handle and manage sales reports well, quickly and accurately, for that it takes accuracy, accuracy, and speed, so that the report is completed on time, besides that it also requires maturity in making reports, so that data reported correctly according to facts in the field and any data reported can be trusted and can be accounted for. The formulation of the problem in this paper is as follows: 1. What are the Roles of Administrative Staff in Handling Sales Reports at PT. Sinar Perdana Adimulia West Jakarta? 2. How to prepare a good, fast, accurate and accountable sales report in accordance with company needs?

Keywords: Profit, Efficient, Competition, Administrative Staff, Sales 
PENDAHULUAN

\section{Latar Belakang}

\section{Keberhasilan sebuah perusahaan \\ dinilai dari kemampuannya dalam} memperoleh laba. Dengan laba yang diperoleh, perusahaan dapat mengembangkan bisnisnya lebih luas. Semakin besar volume jual maka akan semakin besar laba yang diperoleh sebuah perusahaan. Dalam suatu perusahaan terdapat banyak faktor yang menuntut pihakpihak yang berkaitan untuk bekerja menjalankan operasional perusahaan sehingga tercapai hasil yang sesuai dengan harapan perusahaan. Selain itu, perusahaan juga menuntut agar pihak-pihak berkaitan dapat bekerja lebih efisien agar mampu bersaing dengan kompetitor.

Persaingan yang semakin kuat di era globalisasi ini, membuat perusahaan harus bekerja lebih maksimal baik yang terdapat dalam eksternal maupun internal perusahaan. Dengan kerjasama yang baik maka akan tercipta sebuah perusahaan yang mampu bersaing bahkan mencapai target yang diharapkan. Bagian internal maupun ekternal perusahaan harus memiliki kerjasama yang baik untuk menghasilkan sebuah pencapaian yang diharapkan tersebut. Laporan penjualan sangat berperan penting dalam sebuah perusahaan, karena laporan penjualan menunjang kegiatan operasional perusahaan. informasi semua kegiatan yang berhubungan dengan penjualan yang disajikan dalam bentuk catatan dan analisa penjualan. Laporan juga memiliki peranan penting dalam pengambilan keputusan oleh perusahaan, dimana keputusan yang diambil dalam bentuk pemasaran, penentuan harga, strategi penjualan, metode penjualan dan rencana yang akan dieksekusi oleh perusahaan untuk langkah selanjutnya.

Untuk itu laporan penjualan sangat berperan penting dan menjadi bagian vital dalam sebuah perusahaan, karena laporan penjualan berfungsi sebagai acuan sebuah perusahaan apakah perusahaan tersebut mengalami peningkatan atau penurunan, apakah perusahaan tersebut mengalami keuntungan atau kerugian, dan seberapa besar pencapaian target yang dihasilkan dalam sebuah penjualan.

Laporan penjualan itu sendiri diproses sedemikian rupa guna membantu bagian pemasaran untuk menganalisa penjualan dan memantau produktivitas team salesnya dilapangan. Laporan penjualan sebagai media penyampaian informasi yang terjadi pada kegiatan penjualan. Sehingga dalam pembuatannya dibutuhkan seorang staf administrasi yang mampu menangani dan mengelola laporan penjualan dengan baik, cepat dan akurat sesuai kondisi yang terjadi di lapangan.

\section{Laporan penjualan berisi kumpulan}


Berdasarkan latar belakang tersebut maka penulis tertarik untuk mengambil judul "Peran Staf Administrasi Dalam Menangani Laporan Penjualan Pada PT. Sinar Perdana Adimulia Jakarta Barat ".

\section{Identifikasi Masalah}

Berdasarkan latar belakang diatas yang telah diuraikan dapat di identifikasi masalah sebagai berikut :

1. Peran Staf Administrasi dalam Menangani Laporan Penjualan Pada PT. SINAR PERDANA ADIMULIA Jakarta Barat belum maksimal.

2. Adanya kendala dalam menyusun dan proses membuat laporan yang baik dan benar dan tepat waktu sesuai kebutuhan perusahaan.

\section{Perumusan Masalah}

Berdasarkan identifikasi masalah, maka penulis merumuskan permasalahanpermasalahan sebagai berikut :

1. Apa saja Peran Staf Administrasi Dalam Menangani Laporan Penjualan Pada PT. SINAR PERDANA ADIMULIA Jakarta Barat?

2. Bagaimana cara menyusun laporan penjualan yang baik, cepat, akurat dan dapat dipertanggung jawabkan sesuai dengan kebutuhan perusahaan?

\section{HASIL DAN PEMBAHASAN}

\section{Tugas dan Tanggung Jawab Staf Administrasi Penjualan Pada PT. Sinar Perdana Adimulia}

Sebagai perusahaan yang bergerak dibidang penjualan alat telekomunikasi, perusahaan ini banyak memiliki kerjasama dengan berbagai perusahaan, toko-toko dan pelanggan-pelanggan secara retail. Produk yang dijual pun biasanya dalam bentuk corporate, konsinyasi dan retail yang dijual langsung kepada costumer perorangan. Berikut alur penjualan yang penulis kerjakan sebagai Staf Administrasi Penjualan Pada PT. Sinar Perdana Adimulia.

\section{Proses Penjualan Secara Langsung}

Proses penjualan secara langsung memiliki prosedur yang harus dilalui, untuk itu berikut alur penjualan barang sesuai prosedur administrasi pada PT. Sinar Perdana Adimulia Jakarta Barat adalah sebagai berikut :

a. Proses Produksi Barang

Seperti dikatakan diawal bahwa perusahaan menciptakan sendiri produk yang akan dijual kepasaran, dimulai dari merakit perangkat bagian dalam/ software dan kemudian perakitan bagian luar/ hardware perangkat komunikasi ini hingga terbentuk barang siap pakai dan siap dipasarkan. Bagian ini bekerjasama 
dengan product manager, trade marketing, dan bagian Information \& Teknologi (IT) merembukkan dan menggodok dengan matang produk seperti apa yang akan diciptakan untuk dapat memenuhi kebutuhan konsumen dalam kebutuhannya menggunakan alat telekomunikasi yang sesuai dengan kebutuhan saat ini dan tentunya mengikuti perkembangan yang terjadi saat ini, sehingga menghasilkan suatu produk yang diminati oleh seluruh kalangan masyarakat. Dibagian ini staf administrasi turut membantu dalam kelancaran bagian surat menyurat, pembelian spare part dan lain-lain yang diperlukan dalam proses produksi.

b. Analisa penjualan

Setelah produk jadi, barang harus segera dipasarkan. Sebelum barang dipasarkan, harus dilakukan analisa penjualan terlebih dahulu oleh bagian trade marketing biasanya memeriksa, meneliti, dan menentukan dimana produk tersebut akan dijual, tujuannya adalah untuk merencanakan program-program penjualan, penetapan kuota penjualan, observasi produk kompetitor, mensuplai persediaan produk, menetapkan target operasional, menetapkan standar penjualan, dan untuk pengarahan yang lebih baik dari usaha penjualan agar tercapai sesuai target yang ditentukan perusahaan.

Bagian media planner mulai merencanakan tempat-tempat sasaran dimana produk tersebut dapat dipasarkan dan dijangkau oleh banyak kalangan masyarakat, biasanya media planner akan membuka jaringan untuk membuat event-event diberbagai tempat. Bagian staf administrasi juga turut membantu proses administrasinya dalam membuka penghubung berbagai jaringan yang akan bekerjasama, seperti perusahaan, corporate dan master dealer dan toko.

c. Penentuan harga

Penentuan harga jual merupakan hal penting karena merupakan dasar penentuan keuntungan yang diharapkan. Menentukan harga yang disesuaikan dengan biaya produksi, kualitas produk yang akan dijual dan membandingkan harga kompetitor/ pesaing sebelum ditetapkan harga yang pas dan tepat.

d. Pemasaran produk

Pemasaran produk menentukan performa perusahaan dalam memperkenalkan produk yang akan dijual. Biasanya melakukan pemasaran produk seperti promosi melalui sosial media, iklan, spanduk, flyer, menentukan tempat jual yang strategis, memberikan souvenir gratis, tujuannya agar produk dikenal secara luas ke masyarakat. 
e. Persediaan Barang/ stok

Memastikan bahwa produk yang akan dijual tersedia digudang dalam jumlah yang memadai dan memastikan barang yang tersedia digudang dalam keadaan baik dan tidak mengalami kerusakan.

f. Penawaran harga

Apabila pelanggan berminat dengan produk yang ditawarkan, biasanya pelanggan diberi peluang untuk melakukan penawaran harga, pelanggan akan menegosiasi harga dan melakukan kesepakatan apabila harga sudah sesuai.

g. Pemesanan (Penerimaan order dari pelanggan/ dealer/ toko)

Pada saat pelanggan melakukan pemesanan produk, maka alur pemesanannya adalah sebagai berikut:

1) Pemesanan/order diterima oleh staf administrasi dalam bentuk PO melalui email. Didalam surat order terdapat nama perusahaan pelanggan, alamat, no handphone, jumlah unit pesanan, harga, total harga pesanan.

2) Kemudian PO tersebut di verifikasi, verifikasi mencakup nama pelanggan, alamat, jumlah barang yang dipesan pelanggan. Staf administrasi akan membalas surat pesanan tersebut untuk menyatakan bahwa barang yang dipesan tersedia, kosong ataupun masih preorder.

1) Setelah di verifikasi kemudian, dimasukkan / di input sebagai data perusahaan kedalam sistem komputer perusahaan untuk dapat dilakukan proses berikutnya.

2) Selanjutnya staf administrasi akan berkoordinasi dengan bagian gudang dan membuatkan surat permintaan barang keluar yang akan diberikan kepada bagian gudang untuk proses persetujuan pengeluaran barang dari gudang (stock request).

h. Pembuatan surat tagihan/ faktur/ invoice Staf administrasi bertugas membuat surat tagihan/ invoice/ faktur yang ditujukan kepada pelanggan untuk menyatakan jumlah harga yang harus dibayar oleh pelanggan sesuai pesanan yang dibuat oleh pelanggan, serta menyiapkan copy faktur untuk diteruskan bagi kepentingan pencatatan penjualan oleh bagian keuangan, bagian persediaan, bagian jurnal dan laporan. 
i. Penagihan Pelanggan

Setelah pembuatan faktur, kemudian staf administrasi kemudian akan mengirim faktur tersebut kepada pelanggan sebagai penagihan, dan pelanggan harus membayar tagihan sesuai jumlah pesanan dan harus membayar sebelum jatuh tempo yang ditentukan. Apabila pelanggan tidak membayar sesuai tagihan atau melewati jatuh tempo, maka staf administrasi akan menghubungi dan menanyakan langsung kendala yang dihadapi pelanggan, dan membantu memberikan solusi atas keterlambatan pembayaran.

j. Pengiriman barang

Setelah pembayaran diterima, bagian keuangan akan memverifikasi dan menginformasikan kepada staf administrasi bahwa pelanggan sudah membayar sesuai tagihan dan staf administrasi akan berkoordinasi dengan bagian persediaan/ stok gudang untuk memproses pengiriman barang, bagian gudang akan menyiapkan pesanan pelanggan sesuai dengan pemesanan, dan mengirimkannya ke alamat yang ditujukkan pelanggan.

k. Penerimaan barang/ Delivery Order (DO) Staf administrasi bertugas membuat surat penerimaan barang atau Delivery Order (DO) untuk memastikan bahwa barang yang dikirimkan benar-benar diterima oleh pelanggan. Surat penerimaaan barang ini dikirim bersamaan dengan pengiriman barang ke pelanggan. Apabila barang sudah diterima dengan baik, surat akan ditanda tangani pelanggan, dan pelanggan akan mengkonfirmasi penerimaan barang kepada staf administrasi. Surat penerimaan barang akan dibawa kembali oleh bagian gudang untuk disampaikan kepada staf administrasi.

1. Return

Setelah barang diterima pelanggan, apabila ada barang yang dikirimkan mungkin terjadi kerusakan, kekurangan atau kendala dalam kondisi barang, maka pelanggan akan melaporkan masalah ini kepada staf administrasi dan kemudian akan dilakukan penukaran barang (return).

m. Pembuatan laporan penjualan

Apabila proses transaksi jual beli sudah selesai, staf administrasi kemudian bertugas membuat laporan hasil kegiatan penjualan perusahaan sebagai bukti, data atau arsip yang kemudian disimpan kedalam dokumen perusahaan, dan akan dilaporkan kepada atasan. Staf administrasi akan membuat dan melakukan laporan secara berkala kepada atasan, mulai dari laporan penjualan harian, laporan penjualan mingguan, laporan penjualan bulanan, laporan 
penjualan per tiga bulan dan laporan penjualan tahunan.

Dari laporan penjualan ini dapat kita ambil sebagai acuan bagian gudang untuk mengetahui update persediaan barang/ stock terbaru, total penjualan yang dicapai perminggu, perbulan, pertahun, memonitoring penjualan apakah mengalami penurunan atau peningkatan, menghitung keuntungan/ laba yang dihasilkan perusahaan, mengetahui aktivitas penjualan apakah target yang ditetapkan tercapai atau tidaknya, membantu mengevaluasi penjualan, bahkan dari hasil laporan penjualan, perusahaan dapat menentukan target kedepannya.

Daftar urutan proses laporan penjualan diatas seperti siklus yang berputar. Setelah membuat laporan penjualan, staf administrasi harus melaporkan hasil kepada atasan dan atasan akan kembali lagi melakukan proses analisa penjualan, analisa kompetitor, analisa pencapaian/ target dan hal lainnya yang menyangkut penentuan strategi penjualan selanjutnya, sehingga perusahaan dapat terus berjalan dan berkembang sesuai yang diharapkan dan menerima keuntungan sesuai target yang ditentukan perusahaan. Dan staf adminitrasi harus memastikan proses transaksi, proses keluar masuk barang, dan alur penjualan diatas sesuai prosedur yang ditentukan oleh perusahaan dan memastikan pula prosesnya berjalan dengan baik dan lancar.

\section{Proses Penjualan Secara Tidak Langsung}

Teknologi internet sudah terbukti merupakan salah satu media informasi yang efektif dan efisien dalam penyebaran informasi yang bisa di akses siapa saja, kapan saja dan dimana saja, oleh karena itu teknologi internet mempunyai efek yang besar juga dalam perdagangan atau bisnis. Calon pembeli dapat menghemat waktu dan biaya, penjual dan pembeli dapat melakukan proses transaksi jual beli tanpa harus bertemu secara langsung.

Biasanya dinamakan penjualan secara online. Penjualan onlinel proses penjualan secara tidak langsung atau biasa disebut juga $e$ commerce, memiliki alur sebagai berikut.

1. Menyediakan Produk

Memastikan bahwa produk yang akan dijual/diiklankan tersedia stok nya.

2. Memasarkan Produk

Mengiklankan produk yang akan dijual dan menginformasikan harga jual produk. Biasanya produk didisplay di toko online tersebut.

\section{Menerima Order}

Apabila pembeli berminat dengan produk yang ditawarkan, maka pembeli akan memesan produk tersebut, dan penjual akan menerima notifikasi pesanan dari 
pembeli yang harus segera dikirimkan dalam batas waktu tertentu.

4. Input Data Pembeli

Penjual akan menginput data pembeli berupa identitas seperti nama, no handphone, alamat, nama produk, serta jasa pengiriman. .

5. Input Transaksi Penjualan

Penjual menginput pula transaksi penjualan yang akan dijadikan data/ dokumen administrasi yang kemudian akan dimasukkan kedalam laporan penjualan.

\section{Proses Transaksi}

Pada saat pembeli melakukan pemesanan pada point 3 diatas, Pembeli juga harus melakukan proses pembayaran secara online, berupa transfer via bank, alfamart, atau aplikasi pembayaran lainnya sesuai pilihan pembeli.

7. Menerima Konfirmasi Pembayaran

Penjual akan menerima konfirmasi bahwa produk yang dipesan sudah dibayarkan oleh pembeli. Namun dalam tahap ini, dana belum diterima oleh penjual, dan masih tertahan di sistem aplikasi e-commerce.

8. Mengirimkan Barang Pesanan

Setelah menerima konfirmasi pembayaran dari sistem aplikasi, maka penjual harus mengirimkan produk yang sesuai dengan harga, type, warna yang diinginkan pembeli. Penjual harus mengirimkan pesanan sesuai waktu yang ditentukan oleh toko online, apabila penjual tidak mengirimkan sesuai waktu yang ditentukan, maka pesanan dianggap batal oleh toko tersebut, dan uang akan dikembalikan ke pembeli.

9. Penerimaan Barang

Apabila beberapa hari kemudian proses pengiriman produk telah sampai ke pembeli, maka sistem aplikasi akan memberi konfirmasi bahwa barang yang dikirim telah sampai tujuan.

10. Transaksi Selesai

Traksaksi yang terselesaikan dengan baik, maka penjual dapat memeriksa rekening, dan dana dari penjualan akan masuk secara otomatis ke rekening penjual dan proses transaksi selesai.

Dari proses penjualan yang menjadi tugas staf administrasi diatas, maka dapat disimpulkan, terdapat dua macam proses penjualan. Selain penjualan secara kongkrit atau barang tersedia di tempat, terdapat juga penjualan online berbasis $e$ commerce melalui internet, yang dikelola oleh bagian penjualan. Melalui aplikasi online shop seperti shopee, tokopedia, bukalapak, lazada, elevenia, blibli kita dapat melakukan penjualan produk secara cepat dan mudah sehingga dapat membantu meningkatkan penjualan dan pencapaian target penjualan perusahaan. 
Kendala Yang Dihadapi Staf Administrasi jatuh tempo, tidak membayar sesuai tagihan, Dalam Proses Pembuatan Laporan Penjualan staf administrasi harus mem-follow up pada PT. SINAR PERDANA ADIMULIA. kembali pelanggan-pelanggan tersebut dan

Staf administrasi penjualan harus bekerja secara dua arah, pertama, pada saat pelanggan ingin membeli produk, staf administrasi harus menangani proses sesuai prosedur yang ditentukan oleh sistem perusahaan dan memastikan agar produk yang dipesan pelanggan dapat diterima dengan baik sehingga pelanggan dapat merasakan kenyamanan dan kepuasan dalam membeli. Selain itu yang kedua, staf administrasi juga dituntut untuk membuat laporan hasil penjualan secara cepat, tepat dan akurat agar laporan penjualan yang dihasilkan sesuai dengan kebutuhan perusahaan, karena laporan penjualan akan disampaikan kepada atasan dan dari laporan penjualan pula perusahaan menjadikan acuan dan ukuran pencapaian target penjualan perusahaan tersebut.

Dalam proses penanganannya staf administrasi harus menghadapi berbagai macam kendala, kendala dalam proses transaksi, kendala dalam proses pengiriman barang, kendala ketika barang tidak sesuai permintaan pelanggan, dan ditambah lagi staf administrasi harus menghadapi banyak pelanggan/ konsumen dengan berbagai macam karakternya, ditambah apabila pelanggan terlambat membayar melewati membantu memberikan solusi atas kendalakendala yang dihadapi pelanggan.

Dari sisi perusahaan, staf administrasi juga harus menghadapi beberapa kendala, staf administrasi harus terpacu dengan waktu dalam membuat laporan setiap minggu dan bulannya agar laporan dapat sampai tepat waktu ke tangan pimpinan, kendala apabila data-data yang dikumpulkan untuk membuat laporan belum lengkap, selisih barang masuk dan barang keluar, membuat staf administrasi harus mengkroscek ulang data dan alur penjualan, untuk itu diperlukan koordinasi dengan bagian gudang, selisih keuangan harus dikoordinasikan kembali dengan bagian keuangan, serta laporan-laporan aktivitas lainnya yang harus dikroscek ulang kepada bagian yang bersangkutan. Bahkan seringkali staf administrasi menerima tugastugas yang bersifat urgent seperti membuat laporan analisis secara khusus sesuai permintaan atasan/ pimpinan.

Hal-hal tersebut diatas membuat pekerjaan staf administrasi dan proses administrasi banyak mengalami kendala dan hambatan, untuk itu dibutuhkan ketelitian, kesabaran dan kerjasama dari berbagai pihak yang berkaitan, agar hasil laporan staf administrasi memuaskan dan dapat diterima 
atasan, meskipun pada prosesnya banyak mengalami kendala dan hambatan.

\section{PENUTUP}

\section{Kesimpulan}

Dari keseluruhan uraian dan hasil pengamatan pada pembahasan masalah mengenai Peran Staf Administrasi Dalam Menangani Laporan Penjualan Pada PT. SINAR PERDANA ADIMULIA, penulis dapat membuat kesimpulan sebagai berikut :

1. Peran staf administrasi dalam menangani laporan penjualan pada PT. SINAR PERDANA ADIMULIA sangatlah penting karena staf administrasi membantu dalam proses kelancaran transaksi penjualan antara perusahaan, corporate dan pelanggan. Sehingga proses jual beli dapat berjalan dengan baik.

2. Di sisi perusahaan, staf administrasi juga tidak kalah penting, perusahaan sangat membutuhkan hasil laporan penjualan sebagai acuan tolak ukur penilaian dan pencapaian sebuah perusahaan, staf administrasi merupakan bagian terpenting dari sebuah perusahaan sehingga data dan dokumen yang dibutuhkan perusahaan dapat dikelola dan ditangani dengan baik guna menunjang kegiatan operasional perusahaan.
3. Kendala yang dihadapi staf administrasi dalam menangani prosedur penjualan dan menangani laporan penjualan, membuat staf administrasi menyadari bahwa seorang staf administrasi penjualan dituntut harus dapat menangani laporan dengan cepat, tepat dan akurat.

\section{Saran}

Dari kesimpulan yang penulis kemukakan diatas, penulis akan memberikan beberapa saran untuk kedepannya harapan penulis semoga bisa dijadikan dasar dalam upaya mengatasi permasalahanpermasalahan yang dihadapi perusahaan dalam menangani proses pembuatan laporan penjualan.

1. Sebaiknya sistematika laporan penjualan dapat dibuat lebih detail lagi dan dalam prosedurnya laporan yang dibuat membutuhkan sistem yang lebih komputerisasi agar memudahkan staf administrasi dalam membuat laporan secara cepat, tepat dan akurat.

2. Melihat betapa pentingnya staf administrasi dalam sebuah perusahaan, bagian perlu dibekali dengan kemampuan dan skill yang cukup agar dalam menangani pekerjaannya, staf administrasi dapat menyelesaikan pekerjaannya dengam hasil yang semakin 
baik dan kinerja yang semakin meningkat demi kemajuan perusahaan.

\section{DAFTAR PUSTAKA}

\section{Sumber Buku}

Caroline F.Ch. Lawalata, Panduan Lengkap Pekerjaan Sekretaris, Jakarta: Indeks. 2018

Donni Juni Priansa, Manajemen Sekretari Perkantoran, Jakarta: Pustaka Setia. 2017

Donni Juni Priansa \& Fenny Damayanti, Administrasi \& Operasional Perkantoran, Bandung: Alfabeta. 2015
Dr. Harbani Pasolong, M.Si., Metode Penelitian Administrasi Publik, Bandung: Alfabeta. 2013

Durotul Yatimah, Kesekretarisan Modern \& Administrasi Perkantoran, Jakarta: Pustaka Setia. 2018

Khaerul Umam, S.I.P., M.Ag., M.SI., Manajemen Perkantoran, Bandung: Pustaka Setia. 2014

Sedarmayanti, Manajemen Perkantoran Modern, Jakarta: Mandar Maju. 2018.

The Liang Gie, Administrasi Perkantoran Modern, Yogyakarta: Liberity. 2007

Fitria Aprilyani. Membuat Laporan Penjualan di 